\title{
LANDASAN ONTOLOGIS, AKSIOLOGIS, EPITESMOLOGIS ALIRAN FILSAFAT ESENSIALISME DAN PANDANGANYA TERHADAP PENDIDIKAN
}

Oleh:

Bethari Widiya Hardanti

Universitas Negeri Malang

Email: bwidiyahardanti@gmail.com

\begin{abstract}
Abstrak
Filsafat merupakan ilmu pengetahuan yang menyelidiki adanya sebab dan akibat dari segala sesuatu. Filsafat modern banyak dikenal dengan sebutan filsafat pendidikan. Filsafat pendidikan memiliki beberapa aliran yang salah satunya yaitu aliran filsafat pendidikan esensialisme. Esensialisme merupakan aliran yang berakar pada suatu pembelajaran mata pelajaran yang bersifat dasar. Esensinya menunjuk pada sesuatu yang perlu tentang suatu objek, disiplin, subjek dan suatu contoh. Aliran filsafat esensialisme menekankan pada kebudayaan, keterampilan, dan pengetahuan serta memperkuat nilai kedisiplinan sehingga dalam praktiknya pada pendidikan aliran ini menegaskan bahwa sekolah-sekolah harus tetap mempertahankan metode-metode pembelajaran yang tradisional. Pembelajaran menggunakan metode teacher centeered dimana dalam proses belajar mengajar guru berperan sebagai mediator yang mentranfer ilmu pengetahuan kepada peserta didik, sedangkan peserta didik hanya memiliki tugas belajar dan tidak dianjurkan mengatur dan mengelola kelas sehingga para peserta didik menjadi pasif.
\end{abstract}

\section{Kata Kunci: Filsafat, Esensialisme, Pendidikan}

\begin{abstract}
Philosophy is a science that investigates the causes and effects of everything. Modern philosophy is widely known as the philosophy of education. Philosophy of education has several streams, one of which is the philosophy of education essentialism. Essentialism is a flow that is rooted in a basic subject learning. Its essence refers to something necessary about an object, discipline, subject and an example. The flow of essentialism philosophy emphasizes culture, skills, and knowledge and strengthens the value of discipline so that in practice this flow of education emphasizes that schools must maintain traditional learning methods. Learning uses the teacher centeered method where in the teaching and learning process the teacher acts as a mediator who transfers knowledge to students, while students only have learning tasks and it is not recommended to organize and manage classes so that students become passive.
\end{abstract}

Keywords: Philosophy, Essentialism, Education

\section{PENDAHULUAN}

Menurut A. Malik dalam Mustajib (2016), filsafat merupakan hal yang penting untuk menjadi dasar pendidikan karena filsafat banyak melahirkan pemikiran yang teoritis dalam dunia pendidikan. Maka dari itu para pendidik seharusnya mengetahui tentang ide-ide pendidikan karena hal tersebut dapat mengontrol proses berjalannya pendidikan. Filsafat dibutuhkan 
dalam praktik pendidikan guna mencapai tujuan. Kegiatan pendidikan merupakan objek kajian dari filsafat pendidikan.

Filsafat

pendidikan

merupakan dua hal yang disatukan.

Kata filsafat berasal dari bahasa

Yunani yakni Philo yang berarti cinta atau dalam arti luasnya yaitu ingin dan shopia yang berarti kebijakan. Sedangkan menurut UU No 20 tahun 2003 tentang system Pendidikan Nasional pada pasal 1 ayat (1) "Pendidikan adalah usaha sadar dan terencana untuk mewujudkan suasana dan proses pembelajaran agar peserta didik secara aktif mengembangkan potensi dirinya untuk memiliki kekuatan spiritual keagamaan, pengendalian diri, kepribadian, kecerdasan, akhlak mulia, serta keterampilan yang diperlukan dirinya, masyarakat, bangsa dan negara". Filsafat pendidikan merupakan pelaksanaan pendidikan yang berdasarkan pandangan filsafat dan kaidah filsafat yang menekankan pada pelaksanaan prinsip-prinsip dan kepercayaan yang menjadi dasar filsafat umum untuk menyelesaikan masalah pendidikan (Mustajib, 2016) Dalam dunia pendidikan filsafat modern memiliki nama lain yakni filsafat pendidikan. Filsafat pendidikan memiliki berberapa aliran atau mahzab tentang landasan pelaksanaan pendidikan dari perspektif yang berbeda-beda. Aliranaliran filsafat pendidikan meliputi: aliran filsafat progresivisme, aliran filsafat idealisme, aliran filsafat parenialisme, aliran filsafat esensialisme, dan aliran filsafat pragmatisme. Dalam artikel ini penulis akan menguraikan tentang aliran filsafat esensialisme yang berjudul "landasan ontologis, epistemologis, aksiologi aliran filsafat esensialisme dan pandnagannya terhadap pendidikan".

\section{METODE PENELITIAN}

Dalam penulisan artikel ini penulis menggunakan metode studi kepustakaan (Library Research). Studi kepustakaan merupakan metode yang dalam mengumpulkan data dengan menggunakan bahan bukubuku, artikel, jurnal yang terdapat di internet serta hasil peneliti terdahulu untuk dijadilkan sumber atau rujukan. Kegiataan pencarian dan pengumpulan sumber dilaksanakan dengan sistematis yaitu melalui langkah-langkah pengumpulan data, analisis data dan interprestasi data pustaka yang telah berhasil penulis kumpulkan untuk menjawab permasalahan yang dihadapi dalam proses penulisan artikel ini.

\section{HASIL DAN PEMBAHASAN}

Aliran Filsafat Esensialisme

Aliran filsafat esensialisme merupakan aliran filsafat yang mengharapkan manusia untuk kembali atau tidak kebudayaan lama yang dianggap berkontribusi membuat kebaikan-kebaikan bagi kehidupan manusia. Kebudayaan lama yang dijadikan pedoman adalah kebudayaan peradaban masa Renaisance. Dimana Renaisance merupakan zaman laahirnya kembali 
ilmu pengetahuan dan kesenian. Esensialisme merupakan aliran filsafat yang lahir dari dua aliran yakni aliran idealisme dan realisme. Aliran esensialisme disebut sebagai salah satu aliran filsafat modern karena merupakan konsep yang meletakkan sebagian ciri alam pikir yang modern. Esensialisme muncul karena merupakan bentuk reaksi terhadap simbolisme mutlak dan dogmatis yaang terjadi pada abad pertengahan (Thaib M.I, 2015:734).

\section{Menurut} esensialisme pendidikan harus berpijak pada nilainilai yang jelas dna tahan lama dan stabil. Esensialisme juga menyebutkan pendidikan sebagai pemeliharaan kebudayaan karena aliran ini memandang bahwa adanya gejala-gejala penyimpangan kebudayaan masa lalu dalam kebudyaan modern. Berikut merupakan ciri-ciri filsafat pendidikan esensial menurut William C. Bagley dalam Thaib M.I (2015):

1. Minat yang kuat dan tahan lama tumbuh dari upaya belajar awla yang memikat perhatian bukan dari dorongan dari dlaam diri siswa.

2. Pengawasan, pengarahan dan bimbingan orang dewasa sangat melekat pada masa balita sehingga menimbulkan ketergantungan pada manusia.

3. Menegakkan sikap kedisiplinan merupakan cara yang diperlukan dalam mencapai tujuan pendidikan

4. Teori pendidikan esensialisme sangat kuat dan kokoh
Sedangkan menurut Khobir dalam Helaludin (2018), aliran filsafat esensialisme memiliki prinsip-prinsip diantaranya: 1) pendidikan lebih menekankan pada kedisiplinan, 2) guru dituntut inisiatif dalam suatu pembelajaran, 3) pendidikan merupakan proses asimilasi dari subject matter yang ditentukan, 4) sekolah harus tetap mempertahankan metode pembelajaran tradisional khusunya yang berkaitan dengan kedisiplinan, 5) kesejahteraan umum merupakan tujuan dari pendidikan. Pandangan esensialisme ingin membekali manusia supaya terhindar dari sikap buruk melalui nilai kebudayaan. Gerakan esensialisme lahir pada tahun 1930 yang dipelopori olwh William C. Bagley, Isac L Kandel dan Frederick Breed.

\section{Landasan Ontologis, Aksiologis, Epitesmologis Aliran Filsafat Esensialisme}

a. Landasan ontologis esensialisme Landasan ontologi merupakan bidang filsafat yang mengkaji hakikat keberadaan sesuatu sesuai dengan tata hubungan yang sistematis berdasarkan hukum sebab akibat. Landasan ontologis filsafat esensialisme menganggap bahwa dunia dikuasai oleh aturan-aturan baik yang disesuaikan dengan tata alam. Nilai-nilai luhur dijadikan ketetapan untuk menyesuaikan dengan aturan kosmis (Habibah S, 2019:36). Dalam filsafat esensialisme manusia memiliki tujuan umum yakni hidup bahagia di 
dunia dan akhirat. Esensialisme dilandasi oleh aliran realisme objektif dan idealisme objektif. Menurut Jalaludin \& Abdullah (2010) dalam Rukiyati \& Purwastuti L.A (2015:45) Realisme objektif memiliki pandangan yang sistematis tentang alam dan manusia. Realisme objektif melahirkan ilmu-ilmu fisika yang memiliki prinsip bahwa alam fisik dapat dipahami melalui tata yang baik. Sedangkan idealisme objektif memiliki pandangan bahwasanya manusia sebagai makhluk yang tidak dapat terpisahkna dengan alam semesta (Abass E, 2015:108). Pandangan idealisme objektif memiliki sifat menyeluruh dan meliputi segala sesuatu. Karena alam semesta merupakan kekuatan idealisme yang menetapkan pendirian sesuatu yang ada adalah nyata. Isi pengetaahuan filsafat esensialisme mencangkup kesenian dan sesuatu yang mampu menggerakan keinginan ketetapan manusia.

b. Landasan epistomologi esensialisme

Menurut istilah epistemologi berasal dari bahasa Yunani Episteme yang memiliki arti pengetahuan dan logos yang berarti teori. Epismologi adalah cabang filsafat yang mengkaji tentang asal mula pengetahuan, struktur, metode, dan validasi pengetahuan yang bersifat evaluative, normative, dan kritis. Untuk memahami epistemologi esensialisme dapat dilalui dengan teori kepribadian manusia dimana manusia sebagai refleksi Tuhan. Manusia yang bisa menyadari tentang realitas antara makro-kosmos dan mikro-kosmos akan bisa melihat tingkatan rasio yang dipunyai dan mampu memikirkan alam sehingga manusia bisa menghasilkan pengetahuan yang tepat pada ilmu-ilmu alam, biologi, sosial dan agama. Dalam pendidikan aspek epistemologi yang harus diperhatikan yakni pengetahuan yang bersifat ideal dan spiritual yang bisa membimbing manusia dalam kehidupannya. Menurut Gutek (1974) Rukiyati \& Purwastuti L.A (2015:46), pengetahuan merupakan persatuan antara objek dan subjek yang memiliki sifat intensif, mendalam dan instrinstik yang menghasilkan kolaborasi antara pengamatan, pemikiran, dan kesimpulan kemampuan manusia dalam menyerap objek. Bagi aliran filsafat esensialisme pengetahuan merupakan kolaborasi antara pengetahuan empirisme dan rasionalisme dimana pengetahuan bukan hanya hasil dari pemikiran indrawi melainkan hasil berpikir manusia.

c. Landasan aksiologi esensialisme

Aksiologi merupakan cabang filsafat yang mengkaji nilai kebenaran, keindahan, kebaikan, dan religious yang berasal dari nilai-nilai leluhur hidup manusia. Hakikat nilai merupakan kualitas yang melekat dan menjadi ciri sesuatu yang sudah ada di alam semesta dan dihubungkan dengan kehidupan manusia. Harakhi nilai dikelompokkan menjadi empat tingkatan yakni: (1) nilai kenikmatan, meliputi nilai-nilai yang menyebabkan sesorang senang dan 
mengenakkan secara jasmani, (2) nilai kehidupan, meliputi nilai-nilai yang sangat penting untuk pribadi dalam berkehidupan di masyarakat, (3) nilai spiritual, merupakan nilai kejiwaan yang tidak bergantung pada keadaan jasmani yang meliputi kebenaran, keindahan, dan kebaikan. Landasan ontologi dan landasan epistemologi sangat mempengaruhi landasan aksiologi esensialisme. Nilai etika merupakan hukum kosmos yang bersifat objektif, dimana manusia harus bisa dianggap baik jika banyak berhubungan dan melaksanakan hukum yang tersedia. Manusia esensialisme bernggapan bahwa sikap, tingkah laku dan ekspresi yang timbul dari perasaan dan yang memiliki hubungan terhadap kualitas baik dan buruk.pemikiran paham esensialisme sependapat dengan pandangan realisme terkait dengan etika dimana semua pengetahuan manusia terdapat pada keteraturan lingkup hidupnya. Dengan kata lain perilaku baik atau buruknya manusia pada dasarnya mendapat pengaruh dari keturunan dan lingkungannya. Perilaku manusia merupakan hasil kolaborasi yang muncul karena adanya interaksi antara unsur-unsur pembawa hidup dan pengaruh lingkungan (Rukiyati \& Purwastuti L.A, 2015:47).

\section{Pandangan Aliran Filsafat} Esensialisme Terhadap Pendidikan

1. Pandangan terhadap fungsi sekolah

Menurut Kahar (2014) dalam (Junaidin \& Komalasari, 2019:144)
Para kaum esensialis berpendapat bahwa sekolah merupakan tempat melatih, mengajar, dan mendidik peserta didik supaya bisa berkomunikasi dengan jelas, baik, dan rasional. Dalam setiap kurikulum harus memuat keterampilan inti dimana dalam proses pemelajaran peserta didik harus diberikan pengajaran tentang bagaimana cara membaca, menulis, berbicara dan berhitung. Dalam hal ini sekolah memiliki tanggungjawab besar dalam mengawasi dan memperhatikan peserta didik dalam mempelajari dan memahami keterampilan tersebut. Untuk mengimplementasikan aliran filsafat esensialisme dalam kurikulum sangat diperlukan penggunaan media belajar sebagai sarana dan lingkungan pembelajaran yang layak. Berdasarkan pandangan aliraan filsafat esensialisme, pendidikan di sekolah harus memiliki sifat yang praktis, memberikan pembelajaran yang rasional, dan harus bisa menyiapkan sebuah keterampilan untuk dipraktekan dalam kehidupan sehari-hari peserta didik.

2. Pandangan terhadap tujuan pembelajaran

Menurut aliran filsafat esensialisme pembelaajaran memiliki tujuan yakni untuk melanjutkan warisan budaya dan warisan sejarah dengan menggunakan pengetahuan inti yang telah ada dan bertahan dalam waktu yang lama, dan merupakan suaatu sis kehidupan yang sudah dilakukan pengujian oleh masa yang cukup lama. Tujuan pembelajaran esensialisme yaang 
lainnya yaitu menyiapkan manusia supaya bisa hidup baik melalui sekolah, dimana sekolah berperan mendesain sasaran mata pelajaran yang sudah disesuaikan serta layak digunakan untuk manusia sendiri. Maka dari itu tujuan umum pendidikan esensialisme yaitu menyalurkan warisan budaya dan warisan sejarah dengan menggunakan pengetahuan yang terhimpun dan mampu bertahan dalam waktu yang lama. Pengetahuan tidak berjalan sendiri melainkan diiringi dengan keterampilan, sikap, dan nilai-nilai yang bisa membentuk unsur-unsur inti esensialisme. Oleh karena itu pendidikan harus bisa mengarah pada usaha mencapai tujuan yang berstandart akademik serat pengembangan intelegen yang tinggi (Abas E, 2015:144).

\section{Pandangan} terhadap kurikulum.

Di Indonesia yang termuat dalam kurikulum 2013 merupakan jalan pintas yang tepat dalam menjamin keberlangsungan masa depan peserta didik, dimana berdasarkan pandangan esensialisme pendidikan adalah proses yang menuntut peserta didik mempunyai nilai-nilai yang dijadikan pegangan dalam kehidupan selanjutnya. Dalam pendidikan esensialisme ada 5 tema umum antara lain:

- Dalam kurikulum SD harus menekankan pada gerakan literasi seperti membaca, menulis dan berhitung.

- Di dalam kurikulum sekunder harus terdapat mata pelajaran yang harus mencangkup

pembelajaraan sejarah,

pembelajaran matematika,

pembelajan ilmu alam,

pembelajaran sastra dan

pemeblajaran bahasa.

- Pembelajaran yang sistematis harus memegang teguh kedisisplinan di sekolah.

- Peserta didik harus membudayakan rasa hormat kepada otoritas baik dalam lingkungan sekolah maupun lingkungan masyarakat.

- Peserta didik harus bisa menguasai pembelajaran keterampilan dan subjek.

Dalam praktiknya guru esnsialisme sebelum melakukan pembelajaran inti harus mengetahui dan mengidentifikasi terlebih dahulu kompetensi awal yang dimiliki peserta didik. Setelah itu harus menyusun rencana pembelajaran yang sudah disesuaikan dengan karakteristik siswa dan kompetensi dasarnya. Selanjutnya guru memaparkan esensi dari pembelajaran kepada siswa sehingga siswa dapat memahami esensi yang diperoleh dalam suatu pembelajaran yang dilakukan. Yang terakhir yang harus dilakukan oleh guru adalah penilaian, dimana penilaian yang cocok dengan pandangan esensialisme adalah model penilaian berbentuk essay (Junaidin \& Komalasari, 2019:145). 
4. Pandangan terhadap proses pembelajaran

Berdasarkan pandangan dari aliran filsafat pendidikan esensialisme proses pemebelajaran diharuskan berpusat pada guru atau biasa disebut teacher centered. Dimana pada pembelajaran menggunakan metode yang menyesuaikan dengan krrearifitas dan inisiatif guru. Dalam hal ini guru dituntut mampu menguasai berbagai metode pembelajaran yang sebelumnya harus disesuaikan dan dipertimbangkan dalam penerapan metode yang nantinya bisa menjalankan proses belajar mengajar secara efektif. Pembelajaran yang berpusat pada guru banyak menganggap bahwa peserta didik diyakini tidak benar-benar memahami apa yang diinginkan, mereka belajar cenderung dalam pemaksaan sehingga guru harus mampu melatih peserta didik supaya bisa belajar dengan baik. Maka dari itu latihan mental dijadikan metode utama dalam pembelajaran esensialisme. Contoh dari metode latihan mental antara lain; penugasan, diskusi, dan penguasaan pengetahuan. Dalam aliran filsafat pendidikan esensialisme sekolah disarankan tetap mempertahankan metode-metode tradisional dan menekankan pada disiplin mental (Abas E, 2015:116).

5. Pandangan terhadap pendidik dan peserta didik

Dalam aliran filsafat

pendidikan esensialisme guru merupakan orang yang memiliki peranan yang sama dengan aliran filsafat pendidikan perenialisme. Dimana dalam esensialisme menganggap guru adalah orang yang berperan dalam menguasai lapangaan subjek khusus. Dimana dituntut menajdi contoh atau tauladan dan menjadi panutan digugu dan tiru yang baik bagi peserta didik. Peran guru sangat dominan dalam penguasaan dan mempengaruhi kelas karena guru merupakan penguasa pengetahuan dan juga berwenang sebagai pengawas dalam suatu pembelajaran. Maka dari itu dalam aliran pendidikan esensialisme peran guru adalah sebagai mediator bukan fasilitator. Guru harus memiliki pendidikan yang sesuai dan harus dapat dipercaya sehingga bisa membawa pengaruh yang baik terhadap peserta didik. Sedangkan peserta didik memiliki tugas yaitu belajar. Peserta didik tidak disuruh untuk mengatur pelajaran. Dimana mereka belajar tentang menerima dan mengenal dengan benar nilai-nilai sosial yang timbul untuk digunakan dalam kehidupan sehari-hari. Selain itu juga untuk memperbaiki masa depan sehingga peserta didik nantinya menjadi aanak yang bermanfaat. Maka para esensialisme menyatakan bahwa peserta didik merupakan makhluk rasional pada fakta dan keterampilan pokok yang sudah siap melaksanakan proses berpikir (Abas E, 2015:116).

\section{KESIMPULAN}

Aliran

filsafat esensialisme merupakan aliran filsafat yang mengharapkan manusia untuk kembali atau tidak 
kebudayaan lama yang dianggap berkontribusi membuat kebaikan-kebaikan bagi kehidupan manusia.

Esensialisme juga menyebutkan pendidikan sebagai pemeliharaan kebudayaan karena aliran ini memandang bahwa adanya gejala-gejala penyimpangan kebudayaan masa lalu dalam kebudyaan modern. Landasan ontologis filsafat esensialisme menganggap bahwa dunia dikuasai oleh aturan-aturan baik yang disesuaikan dengan tata alam, epistemologi esensialisme dapat dilalui dengan teori kepribadian manusia dimana manusia sebagai refleksi Tuhan, dan landasan aksiologi esensialisme. nilai etika merupakan hukum kosmos yang bersifat objektif, dimana manusia harus bisa dianggap baik jika banyak berhubungan dan melaksanakan hukum yang tersedia. Pandangan aliran filsafat esensialisme terhadap pendidikan yakni pendidikan dianjurkan tetap melaksanakan metode-metode pembelajaran tradisional yang hgbt6berpusat pada guru dan dalam prossesnya kedisiplinan harus tetap ditegakkan.

\section{DAFTAR PUSTAKA}

Abas, E. (2015). Asas Filosofi Teori

Belajar Esensialisme Dan

Implikasimya dalam

Pendidikan. Lentera, 2, 104120.

Habibah, S. (2019). Kritik Dan

Komentar Pendidikan

Esensialisme. Al-Riwayah, 11, 32-44.

Helaluddin. (2018). Restrukturisasi

Pendidikan Berbasis Budaya:

Penerapan Teori Esensialisme

Di Indonesia. Jurnal Dimensi

Pendidikan Dan

Pembelajaran, 6, 75-82.

Komalassari, J. (2019). Kontribusi

Esensialisme Dalam

Implementasi Kurikulum

2013. JMSP (Jurnal

Manajemen dan Supervisi

Pendidikan), 3, 138-147.

Mustajib. (2016). Filsafat Pendidikan

Hasan Langgulung. El-

Tarbawi: Jurnal Dimensi

Pendidikan Dan

Pembelajaraan, 9, 83-98.

Rukiyati, P. (2015). Mengenal

Filsafat Pendidikan.

Yogyakarta: Uny Press.

Tentang Sistem Pendidikan Nasional. (2003). Undang-Undang No

3. Republik Indonesia.

Thaib, M. (2015). Esensialisme

Dalam Perspektif Filsafat

Pendidikan Islam.

Mudarrisuna, 4, 731-762. 
Reforma: Jurnal Pendidikan dan Pembelajaran Vol.9 No. 2 (2020)

p-ISSN: 2503-1228; e-ISSN: 2621-4172

Undang-Undang RI No 3 Tahun 2003 Tentang Sistem Pendidikan Nasional 